\title{
One slip, and you're dead...
}

\section{The lethal toxins produced by cone snails are in hot demand for neuroscience research, and are being developed as potent drugs. Laura Nelson visits a would-be snail 'farmer', for whom milking time is fraught with danger.}

J on-Paul Bingham fumbles around for a condom. Big Bertha is waiting. There's an awkward pause. "It has to be the non-lubricated kind," he says. Bingham rips open the packet and slips the prophylactic over a small plastic test tube.

Big Bertha is one of Bingham's nine tropical marine cone snails. These colourful creatures are some of the most venomous beasts on the planet. But the powerful poisons they produce can, in tiny doses, help to reveal how nerve cells function - and potentially help to treat conditions from chronic pain to epilepsy.

Currently, most neuroscientists obtain their cone snail toxins from dead animals taken from the wild. But Bingham, a biochemist at Clarkson University in upstate New York, believes that the future lies with cone snail farming. Not only might it help conserve wild populations, he says, but it can also yield a wider range of useful toxins.

'Milking' the live snails is a hazardous business. One false move and Bingham could be dead in half an hour. Using forceps, he dangles a dead goldfish, the same length as Big Bertha, in front of her. Behind the bait, the condom is stretched over the mouth of the plastic tube.

"We tried all sorts of membranes, including sausage skin," says Bingham. "But for this species, condoms are the right thickness and the snails don't like the lubricated ones." Bertha extends her proboscis and, with an abrupt flick, stabs the fish and the condom. She discharges a few microlitres of the toxin into the tube. That's enough to kill ten people.

\section{Violent reaction}

There are about 30 recorded instances of people being killed by cone snails - the molluscs are aggressive if provoked and can penetrate wetsuits with their sharp poisonloaded harpoons, which look like transparent needles. Human victims seem to suffer little pain ${ }^{1}$, because the venom contains an analgesic component.

Today, the venom's painkilling properties are just one facet of a burgeoning field of research and drug development. Australian scientists first separated cone snail venom into its constituent parts in 1977 (ref. 2). Unlike most venomous animals, which produce one or a few poisons, a single snail can produce up to 100 individual toxins.

When it comes to working out what each component does, Baldomero 'Toto' Olivera, a Filipino based at the University of Utah in Salt Lake City, has led the way. Throughout the 1980s, Olivera's students injected venom into the central nervous system of mice and found that different components had different effects - some would send a mouse to sleep, others would make it shake, run in circles or swing its head back and forth. The researchers showed that the different venom components had specific targets in the nervous system - they blocked different ion channels in cell membranes, which control the transmission of impulses by nerves, or specific receptors for the neurotransmitter chemicals that transmit signals from cell to cell ${ }^{3}$.

\section{One snail's poison...}

One venom component, called MVIIA and classified as an $\omega$-conotoxin, causes tremors in mice. Olivera's group has found that it blocks a specific type of calcium channel that has been implicated in chronic neuropathic pain, caused by damage to the nervous system $^{4}$. The toxin has since been developed as a drug called ziconotide and is now in advanced clinical trials for patients with cancer and AIDS who are suffering from pain that cannot be relieved by opiates ${ }^{5}$.

Different groups of conotoxins - most known by various letters of the Greek alphabet - target other ion channels, such as those for sodium and potassium, or receptors and transporters for neurotransmitters such as glutamate, serotonin, neurotensin and noradrenaline $e^{6,7}$. "This is a real pharmaceutical cornucopia waiting to be tapped," says Bruce Livett of the University of Melbourne in Australia, who hopes soon to put

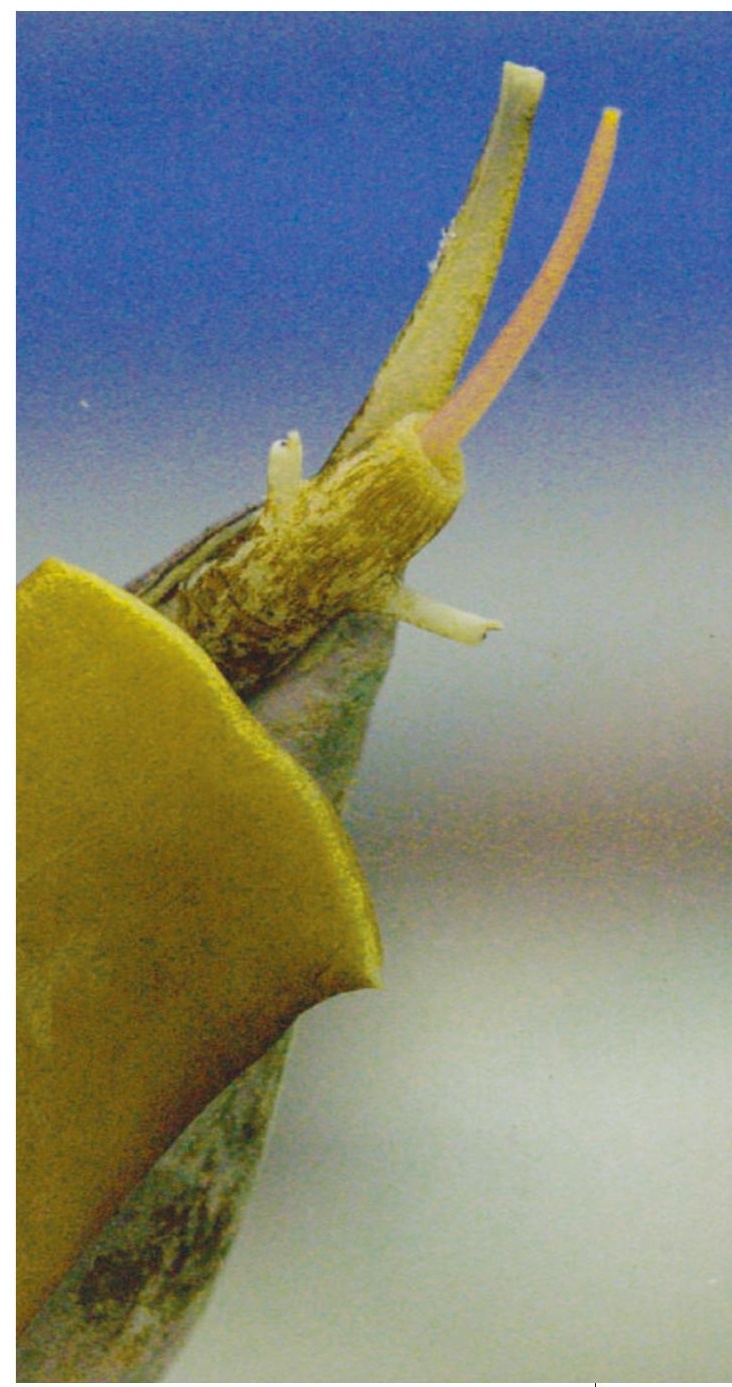

Milking time: Jon-Paul Bingham entices his molluscan menagerie to yield a sample of toxins.

an $\alpha$-conotoxin, known as Vc1.1, into clinical trials for patients with diabetes who are suffering from the neuropathic pain that is a complication of the disease. Another toxin, which blocks a receptor for a specific neurotransmitter, is being investigated as a treatment for epilepsy. The goal is to damp down the hyperactivity that causes epileptic seizures.

In addition to their value as drugs (see Table, below), neuroscientists can use conotoxins as ultraprecise tools to selectively disable particular ion channels, or to block the action of individual neurotransmitters.

\begin{tabular}{|c|c|c|c|c|c|}
\hline Toxin & Class & Species & Condition & $\begin{array}{c}\text { Stage in } \\
\text { development }\end{array}$ & Company website \\
\hline Vc1.1 & $\alpha$ & Conus victoriae & $\begin{array}{c}\text { Neuropathic } \\
\text { pain }\end{array}$ & Preclinical & www.metabolic.com.au \\
\hline CVID & $\omega$ & C. catus & $\begin{array}{l}\text { Neuropathic } \\
\text { pain }\end{array}$ & $\begin{array}{c}\text { Phase II } \\
\text { clinical trials }\end{array}$ & www.amrad.com.au \\
\hline MVIIA & $\omega$ & C. magus & Cancer pain & Phase III & www.elan.com \\
\hline $\mathrm{MrlA} / \mathrm{B}$ & $\chi$ & C. marmoreus & $\begin{array}{l}\text { Neuropathic } \\
\text { pain }\end{array}$ & Preclinical & www.xenome.com \\
\hline Contulakin-G & Contulakin & C. geographus & $\begin{array}{l}\text { Chronic } \\
\text { pain }\end{array}$ & Phase II & www.cognetix.com \\
\hline Conantokin-G & Conantokin & C. geographus & Epilepsy & Preclinical & www.cognetix.com \\
\hline
\end{tabular}




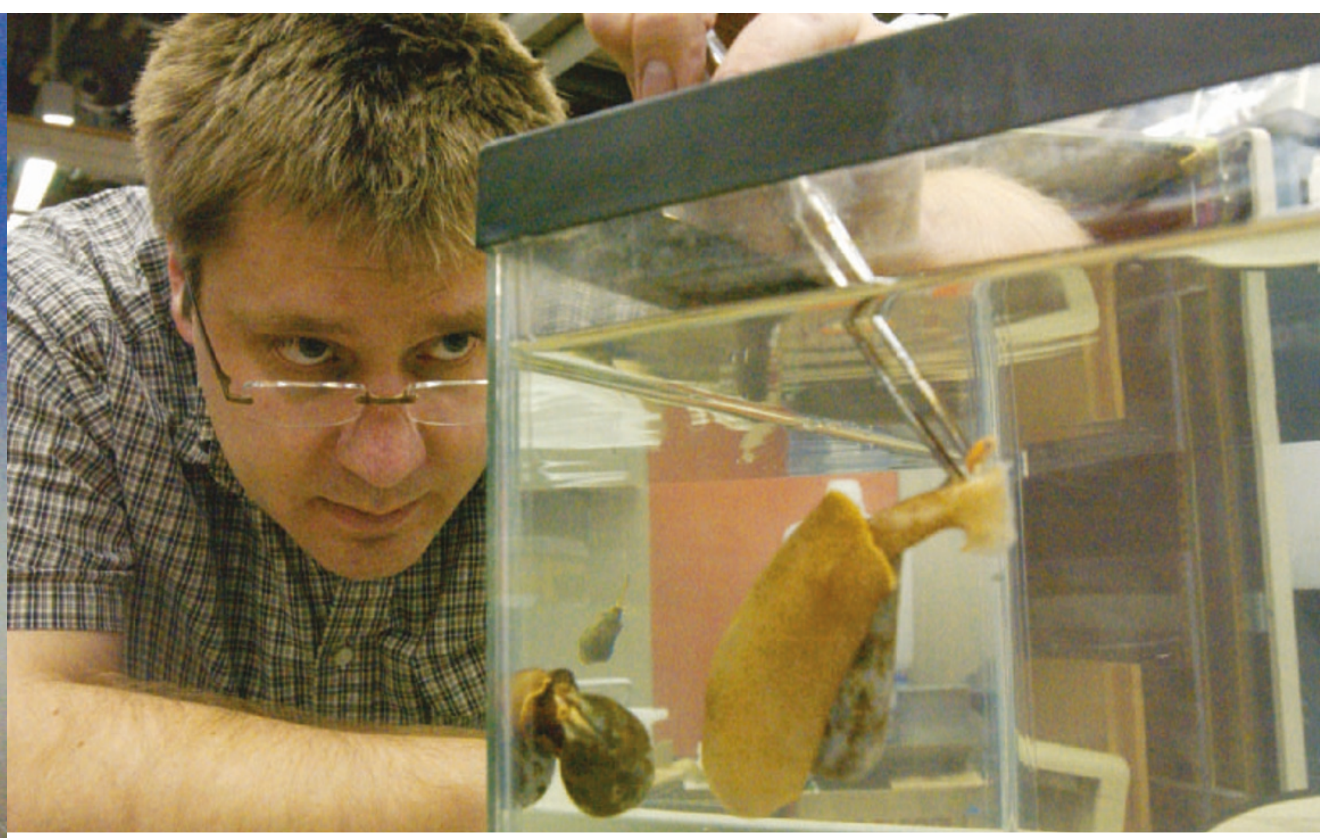

